Marquette University

e-Publications@Marquette

4-1-2007

The Heir of Righteousness and the King of Righteousness: The Priestly Noachic Polemics in 2 Enoch and the Epistle to the Hebrews

Andrei Orlov

Marquette University, andrei.orlov@marquette.edu

Accepted version. The Journal of Theological Studies, Vol. 58, No. 1, (April 2007), p. 45-65. DOI. (C) 2007 Oxford University Press. Used with permission. 


\title{
The Heir of Righteousness and the King of Righteousness: The Priestly Noachic Polemics in 2 Enoch and the Epistle to the Hebrews
}

\author{
Andrei A. Orlov \\ Theology Department, Marquette University \\ Milwaukee, WI
}

\begin{abstract}
It has previously been noted that 2 (Slavonic) Enoch, a Jewish

pseudepigraphon written in the first century $C E$, contains traces of polemics against the priestly Noachic tradition. In the course of the polemics the role of Noah as the pioneer of animal sacrificial practice to whom God reveals the commandments about the blood becomes transferred to other characters of the story, including the miraculously born priest Melchizedek. In light of the polemics detected in 2 Enoch, it is possible that another work written at the same period of time, namely, the Epistle to the Hebrews-a text which like 2 Enoch deals with the issues of blood, animal sacrificial practice, and the figure of Melchizedek-might also contain implicit polemics against Noah and his role as the originator of such practice. It has been noted before that the author of Hebrews appears to be openly engaged in polemics with the cultic prescriptions ( $\delta \imath \kappa \alpha \omega ́ \mu \alpha \tau \alpha \lambda \alpha \tau \rho \varepsilon i \alpha \varsigma$ ) found in the law of Moses and perpetuated by the descendants of Levi. Yet the origin of animal sacrificial practice and the expiatory understanding of blood can be traced to the figure of Noah, who first performed animal sacrifices on the altar after his disembarkation and who received from God the commandment about the blood. By renouncing the practice of animal sacrifices and invalidating the

Journal of Theological Studies, Vol 58, No. 1 (April 2007): pg. 45-65. DOI. This article is (C) Oxford University Press and permission has been granted for this version to appear in e-Publications@Marquette. Oxford University Press does not grant permission for this article to be further copied/distributed or hosted elsewhere without the express permission from Oxford University Press.
\end{abstract}


NOT THE PUBLISHED VERSION; this is the author's final, peer-reviewed manuscript. The published version may be accessed by following the link in the citation at the bottom of the page.

expiatory significance of the animal blood through the sacrifice of Jesus, who in the Epistle to the Hebrews is associated with the figure of Melchizedek, the authors of the Epistle to the Hebrews appear to be standing in opposition not only to Moses and Levi, but also to Noah. Here again, as in 2 Enoch, the image of Melchizedek serves as a polemical counterpart to Noah and the priestly Noachic tradition, which the hero of the Flood faithfully represented.

\section{Introduction}

It has previously been noted that the Epistle to the Hebrews engages in consistent polemic against the figure of Moses and the Mosaic regulations about the sanctuary and the sacerdotal prescriptions depicting animal sacrifices as inferior, temporary offerings as compared with the eternal sacrifice of Jesus. ${ }^{1}$ Notwithstanding the importance of the figure of Moses in the cultic debates in the Epistle to the Hebrews, the targets of the text's polemics may go beyond Mosaic sacrificial precepts and the priestly practices of the descendants of Levi and include other priestly traditions in the Jewish milieu of the late Second Temple period. Recent scholarship has become increasingly aware of the complexity of the social, political, and theological climate of the late Second Temple period when the various sacerdotal groups and clans were competing for the primacy and authority of their priestly legacy. This contentionridden sacerdotal environment created a whole gallery of ideal priestly figures that, along with traditional sacerdotal servants like Levi, Aaron, and Simon, also included other characters of primeval and Israelite history, such as Enoch, Methuselah, Noah, Shem, Melchizedek, Abraham, and others. The choice in depicting primeval heroes as ideal priests does not seem coincidental and provides further support for the intensity of the priestly rivalry in which the primacy of the sacerdotal hero was determined by, among other things, the antiquity of his cultic initiations and practices acquired long before the relevant competitors. In this respect the sacerdotal knowledge and initiations received by Enoch and Noah from God in ante- and post-diluvian time were more ancient than the disclosures about sacrificial rites and sanctuary received by Moses many centuries later on Mount Sinai.

One should note that ideal priestly figures were not the exclusive property of any one group but were often used by several rival traditions for legitimating distinctive priestly genealogies and claims. An illustration of this polemical feature will be shown later in permission has been granted for this version to appear in e-Publications@ Marquette. Oxford University Press does not grant permission for this article to be further copied/distributed or hosted elsewhere without the express permission from Oxford University Press. 
the essay through the ideal priestly figure of Melchizedek, which was used by various, sometimes rival, traditions. ${ }^{2}$

In view of this complexity of the priestly climate of the late Second Temple period, it appears that in his efforts to demonstrate the exclusivity of the priestly figure of Jesus and the superiority of his sacrifice, the author of the Epistle to the Hebrews was not able to ignore other contemporary Jewish priestly traditions by limiting his polemics solely to deconstructing the priestly significance of the Mosaic tradition. In fact, I will argue that along with explicit polemics against Mosaic sacrificial precepts and practices, the Epistle to the Hebrews ventures into more subtle debates with the priestly Noachic tradition, which in the late Second Temple period often stood as an ideological counterpart to the official priestly office associated with the Jerusalem Temple. I will also suggest that the figure of Melchizedek-which, as will be seen, by the first century ce was already adopted in the theological framework of the priestly Noachic tradition-is posited in the Epistle to the Hebrews, as in some Second Temple Jewish texts, as a polemical counterpart to Noah. It seems that by adopting the Melchizedek figure the Epistle to the Hebrews not only explicitly argues against the Mosaic legacy but also implicitly polemicizes with the Noachic tradition, ${ }^{3}$ at the same time using its potential for further enhancement of the priestly profile of the King of Salem who serves in the book as the ideal priestly prototype of Jesus.

\section{Why Melchizedek?}

\section{Melchizedek in 2 Enoch}

As was already noted, in the late Second Temple period the sacerdotal legacy of Mosaic revelation came under fierce attack from some priestly groups. The Epistle to the Hebrews' authors were not the first to challenge the sacerdotal significance of the Mosaic legacy. There was another important priestly trajectory, existing probably from the fourth or third century BCE, that was, as in the later position of the Epistle to the Hebrews, rival to the Mosaic sacerdotal tradition. This trend, which was associated with early Enochic and Noachic materials, attempted to offer a viable ideological alternative to the Mosaic tradition by means of speculating on the pre-Mosaic priestly 
traditions, depicting Enoch and Noah as custodians of the more ancient cultic revelation and practice that had existed long before Levi, Moses, and Aaron. ${ }^{4}$ In this rival paradigm Enoch and Noah were depicted as the priestly figures associated with the celestial and earthly sanctuaries and responsible for establishing the animal sacrificial cult by delivering the first sacrificial halakhot about the expiatory meaning of blood. ${ }^{5}$

The use of such protological figures as Enoch and Noah does not seem coincidental in view of their polemical anti-Mosaic thrust, since these primeval heroes had held their priestly offices long before the son of Amram received his revelation and sacerdotal prescriptions on Mount Sinai. In its polemics against the Israelite prophet, late Enochic tradition adopted in its framework the portfolios of some other preMosaic priestly figures, including the story of the enigmatic priest Melchizedek. An account found in the last chapters of 2 (Slavonic) Enoch, a Jewish text apparently written in the first century CE, gives one of the examples of such adaptation of the figure of Melchizedek. The account seeks to incorporate the enigmatic priest in the framework of Enochic-Noachic cultic tradition by transferring to him the priestly features of Noah and, more specifically, the sacerdotal characteristics of his miraculous birth. It is well known that the birth of Noah occupies an important place in early Enochic and Noachic materials which portray the hero of the Flood as a wonder child. 1 Enoch $106,{ }^{6}$ the Genesis Apocryphon, ${ }^{7}$ and possibly $1 \mathrm{Q} 19^{8}$ depict him with a glorious face and eyes 'like the rays of the sun'. 1 Enoch 106:2 relates that when the newborn Noah opened his eyes, the whole house lit up. The child then opened his mouth and blessed the Lord of heaven. Scholars have previously noted ${ }^{9}$ that the scene of the glorious visage of the young hero of the Flood delivering blessings upon his rising up from the hands of the midwife has a sacerdotal significance and parallels the glorious appearance and actions of the high priest. ${ }^{10}$ The scene manifests the portentous beginning of the priestly Noah tradition. ${ }^{11}$ In 2 Enoch, this prominent part of Noah's biography finds a new niche, where the peculiar details of Noah's story are transferred to another character, Melchizedek. ${ }^{12}$

Scholars have previously pointed out that Melchizedek's birth in Slavonic Enoch recalls some parallels with the birth of Noah in 1 Enoch and the Genesis Apocryphon. ${ }^{13}$ The details of Noah's natal account correspond at several points with the Melchizedek story: permission has been granted for this version to appear in e-Publications@Marquette. Oxford University Press does not grant permission for this article to be further copied/distributed or hosted elsewhere without the express permission from Oxford University Press. 
NOT THE PUBLISHED VERSION; this is the author's final, peer-reviewed manuscript. The published version may be accessed by following the link in the citation at the bottom of the page.

1. Both Noah and Melchizedek belonged to the circle of Enoch's family.

2. Both characters are attested as survivors of the Flood.

3. Both characters have an important mission in the postdiluvian era.

4. Both characters are depicted as glorious wonder-children.

5. Immediately after their birth, both characters spoke to the Lord. 1 Enoch 106:3 relates that 'when he (Noah) arose from the hands of the midwife, he opened his mouth and spoke to the Lord with righteousness'. A similar motif is attested in 2 Enoch $71: 19$, where Melchizedek 'spoke with his lips, and he blessed the Lord'. ${ }^{14}$

6. Both characters were suspected of divine/angelic lineage. $M$. Delcor aYrms that Lamech's phrase in the beginning of the Genesis Apocryphon, 'Behold, then I thought in my heart that the conception was the work of the Watchers and the pregnancy of the Holy Ones', can be compared with the words of Noah in 2 Enoch uttered at the time of examining Melchizedek: 'This is of the Lord, my brother.'15

7. The fathers of both infants were suspicious of the conception of their sons and the faithfulness of their wives. ${ }^{16}$ Thus, in the Genesis Apocryphon, Lamech is worried and frightened about the birth of Noah, his son. Lamech suspects that his wife Bathenosh was unfaithful to him and that 'the conception was (the work) of the Watchers and the pregnancy of the Holy Ones, and it belonged to the Nephil[in]'. ${ }^{17}$ The motif of Lamech's suspicion about the unfaithfulness of Bathenosh found in the Genesis Apocryphon seems to correspond to Nir's worry about the unfaithfulness of Sothonim. 2 Enoch relates that when 'Nir saw her [Sothonim] . . . he became very ashamed about her. And he said to her, "what is this that you have done, $\mathrm{O}$ wife? And why have you disgraced me in the front of the face of all people? And now, depart from me, go where you conceived the disgrace of your womb." '18

8. Mothers of both heroes were ashamed and tried to defend themselves against the accusation of their husbands. Thus, in the Genesis Apocryphon, the wife of Lamech responds to the angry questions of her husband by reminding him of their intimacies: 'Oh my brother and lord! Remember my sexual 
pleasure ... [. . .] in the heat of intercourse, and the gasping of my breath in my breast. ${ }^{19}$ She swears that the seed was indeed of Lamech: 'I swear to you by the Great Holy One, by the King of the hea[vens ... . . . [. . .] that this seed comes from you, [. ..] and not from any foreigner nor from any of the watchers or sons of heav[en]. ${ }^{20}$ In 2 Enoch Sothonim does not explain the circumstances of the conception. She answers Nir: 'O my lord! Behold, it is the time of my old age, and there was not in me any (ardor of ) youth and I do not know how theindecency of my womb has been conceived. ${ }^{21}$

9. Fathers of both sacerdotal infants were eventually comforted by the special revelation about the prominent future role of their sons in the post-diluvian era. ${ }^{22}$

One cannot fail to notice a host of interesting overlaps between the birth of Noah in the Noachic materials and the birth of Melchizedek in 2 Enoch. It appears that the author of 2 Enoch wants to diminish the uniqueness of the priestly career of the hero of the Flood and to transfer his sacerdotal qualities to Melchizedek. The text can therefore be seen as a set of polemical improvisations on the original Noachic themes that attempts to adopt the figure of Melchizedek into the framework of the priestly Noachic tradition. It is clear that Noah's connection with the sacrifices and the commandments about the blood become one of the focal points of the polemical developments. The authors of the Slavonic apocalypse try to deconstruct the figure of Noah through the image of the heavenly Melchizedek, who, according to their story, survives the Deluge, not in the ark of the Flood's hero, but through his translation to heaven on the back of the archangel Gabriel. Here the most significant point of the priestly Noachic tradition is challenged-the animal sacrifices at Noah's disembarkation after the Flood lose their sacerdotal significance as the unique cult-establishing event, since the priest Melchizedek acquires a much loftier celestial appointment and now it is he who is promised by God to become the priest to all priests in the post-diluvian era.

\section{Shem-Melchizedek in Targumic and Rabbinic Materials}

Another example of incorporating Melchizedek's figure in the 
framework of the priestly Noachic tradition can be detected in the prominent typological portrayal of Melchizedek as Noah's oldest son, Shem. This feature may well be an original Noachic-Enochic development since Shem appears to play a very special role in the priestly Noachic tradition. According to Jubilees, Shem was Noah's choice in the transmission of his teaching. From Jub. 10:13-14 we learn that 'Noah wrote down in a book everything . . . and he gave all the books that he had written to his oldest son Shem because he loved him much more than all his sons. ${ }^{23}$ Yet in targumic and rabbinic materials Shem-Melchizedek has been used for the legitimization and neutralization of the rival Noachic trend by placing this trajectory in the framework of traditional sacerdotal settings. In targumic and rabbinic materials Shem therefore serves as an important link that connects the priestly Noachic tradition with the figure of Abraham, by surrendering to him the priestly rights inherited from the hero of the Flood. This theological development has very early historical roots. Identification of Melchizedek as Shem can be found in the Targum, ${ }^{24}$ the Aramaic rendering of the Hebrew Bible. Tg. Neof. on Gen. 14:18 exhibits an exegetical development of this identification: 'And Melchisedech, king of Jerusalem-he is Shem the Great-brought out bread and wine, for he was the priest who ministered in the high priesthood before the most High God. ${ }^{25}$ The Tg. Ps.-J. holds a similar exegetical position: 'the righteous king - that is Shem, the son of Noah-king of Jerusalem, went out to meet Abram, and brought him bread and wine; at that time he was ministering before God Most High.'26

Theological deliberations about Shem-Melchizedek are also attested in talmudic and midrashic materials, including Gen. Rab. 43:1; 44:7, Abot R. Nat. 2, Pirqe R. El. 7; 27, and b. Ned. 32b. While the testimonies found in the targumim appear to be neutral, the evidence found in the midrashim and the talmudim tries to diminish the significance of the priestly Noachic tradition by surrendering its legacy to Abraham and his descendents. Thus, in b. Ned. 32b, the following passage is found:

R. Zechariah said on R. Ishmael's authority: The Holy One, blessed be He, intended to bring forth the priesthood from Shem, as it is written, 'And he [Melchizedek] was the priest of the most high God' (Gen 14:18). But because he gave precedence in his blessing to Abraham over God, He brought it 
forth from Abraham; as it is written, 'And he blessed him and said, Blessed be Abram of the most high God, possessor of heaven and earth, and blessed be the most high God' (Gen 14:19). Said Abraham to him, 'Is the blessing of a servant to be given precedence over that of his master?' Straightway it [the priesthood] was given to Abraham, as it is written (Ps 110:1), 'The Lord said unto my Lord, Sit thou at my right hand, until I make thine enemies thy footstool'; which is followed by, 'The Lord hath sworn, and will not repent, Thou art a priest for ever, after the order of Melchizedek' (Ps 110:4), meaning, 'because of the word of Melchizedek'. Hence it is written, 'And he was a priest of the most High God, [implying that] he was a priest, but not his seed' (b. Ned. 32b). ${ }^{27}$

As one can see, Melchizedek's identification with Shem in rabbinic materials28 exhibits a strong polemical flavour. Their basic message is the building up of the priestly antecedents of Melchizedek (Shem) in the context of transmission of this priestly line to Abraham. b. Ned. $32 \mathrm{~b}$ underlines this polemical thrust by saying of Shem-Melchizedek that 'he was a priest; but not his seed'.

\section{Melchizedek in the Epistle to the Hebrews}

It is now important to underline that in the two aforementioned theological developments attested in 2 Enoch and the targumic materials, which appear to reflect traditions contemporaneous with deliberations found in the Epistle to the Hebrews, the speculations about Melchizedek become associated with the figure of Noah. In 2 Enoch he is depicted as the counterpart of Noah, to whom the text transfers many priestly qualities of the hero of the Flood. In the targumic/rabbinic traditions, Melchizedek's portrayal as the elder son of Noah, Shem, also brings him into the framework of the priestly Noachic tradtion. It is important that in both cases the priestly concerns are pronounced. Another common feature of these accounts is that both speculations about Melchizedek have an anti-Noachic flavor. In 2 Enoch, Melchizedek replaces Noah as the ideal priest. In the targumic and rabbinic speculations, Shem-Melchizedek neutralizes and deconstructs the uniqueness and independence of the Noachic priestly tradition by surrendering its legacy to Abraham and his descendants, including Levi. 
In view of these traditions, it is not entirely impossible that the author of Hebrews was cognizant of these developments, which stemmed from the first-century sacerdotal debates and can ultimately be traced to the Noachic motifs and themes reflected in such Second Temple sources as 1 Enoch, Genesis Apocryphon, and 1Q19. One must take note of scholars' previous suggestions of the possibility that the author of the Epistle to the Hebrews may have been familiar with some extrabiblical Enochic and Noachic traditions. ${ }^{29}$ It is therefore possible that by taking on the figure of Melchizedek, the author of Hebrews, similar to the authors of 2 Enoch or the targumic materials, may also have tried implicitly to appropriate the prominent theological legacy of the priestly Noachic tradition. Another possibility is that the author of the Epistle to the Hebrews could have been cognizant of the developments found in 2 Enoch or the Targum and therefore sought to argue against them. Some traditions found in Hebrews appear to point to this polemical intent.

Thus, both 2 Enoch and targumic passages express concern about the priestly lines and genealogies in connection with Melchizedek. 2 Enoch attempts to incorporate Melchizedek in the priestly Enochic genealogy where Melchizedek becomes a climactic point of the honourable line of the protological priests. ${ }^{30}$ The same tendency can be seen in the targumic materials, where Melchizedek in fact unifies two genealogies: the line of the non-Israelite Noachic sacerdotal tradition and the Israelite line traced to Abraham and Levi. Both targumic and Enochic developments also try to domesticate the figure of Melchizedek historically by assigning to him historical parents and placing him in the framework of Noah's (Targum) and Nir's (2 Enoch) families. Both developments seek to give this abstract and in some ways even ahistorical character from Genesis a certain historical location by placing him in the framework of primeval history. In the context of these developments, Hebrews' insistence on the fact that Melchizedek does not have parents or a priestly genealogy might constitute an attempt to disconnect him from these contemporaneous theological developments, which tried to domesticate his figure by assigning him a specific historical locale or a particular priestly genealogy.

The identification of Melchizedek as the only being without a 'genealogy' ( $\alpha \gamma \varepsilon v \varepsilon \alpha \lambda o ́ \gamma \eta \tau o \varsigma)$ may indicate that the author of 
Hebrews was well aware of Melchizedek's genealogies, similar to those found in 2 Enoch $^{31}$ or Melchizedek's treatise ${ }^{32}$ from the Nag Hammadi library, where the name Melchizedek is incorporated into the sacerdotal lists of the priestly Noachic tradition. ${ }^{33}$

\section{Why not Noah?}

The Epistle to the Hebrews is full of puzzles. One of the most intriguing puzzles for current research is this: why does the author never mention the name of Noah in his debates about animal sacrifices and the expiatory meaning of human and animal ${ }^{34}$ blood? ${ }^{35}$ After all, it is not to Moses and Levi but to Noah that God has decided to reveal for the first time in human history his commandments about the importance of human and animal blood. Noah was also the first person to perform the animal sacrifices on the altar in the Bible. ${ }^{36} \mathrm{He}$ is thus depicted in the biblical and pseudepigraphical sources as the pioneer of expiatory practices involving animal blood, a sacrificial practice that many centuries after him was profoundly challenged by the sacrifice of Jesus. Noah can in many ways be considered as the founder of the old expiatory practice in the same manner that Jesus is the $\alpha \rho \chi \eta \gamma$ ò $\varsigma$ of another expiatory paradigm. By depicting Jesus in this way the Epistle to the Hebrews stands in theological opposition to the long-lasting tradition of animal offerings inaugurated by the hero of the Flood in the post-diluvian world. This perspective, where Jesus is seen as the end of the tradition of which Noah constitutes the beginning, decisively demonstrates the role of Jesus as being not only the polemical counterpart of the intermediate figures of the animal sacrificial tradition, such as Moses or Levi, but also the polemical counterpart of the very founder of this tradition, the hero of the Flood.

Hebrews' theological attempt at renouncing animal sacrifices, depicting animal blood as an inferior expiatory medium in comparison with the human blood of Jesus, seems also to invoke for polemical purposes traces of the Noachic tradition. As we remember, the commandment to Noah about the blood in Genesis 9 specifically warns against shedding human blood on the basis that a human being is fashioned after the image of God. Genesis 9 may thus attest here to the implicit prohibition against human sacrifices, an expiatory practice involving human blood. In the Epistle to the Hebrews, in direct permission has been granted for this version to appear in e-Publications@Marquette. Oxford University Press does not grant permission for this article to be further copied/distributed or hosted elsewhere without the express permission from Oxford University Press. 
opposition to the commandment from Genesis, the expiation is made by the human blood of Jesus, which is proved there to be a more powerful expiatory medium than the blood of calves and goats.

\section{Heir of Righteousness}

This study has already noted that the Epistle to the Hebrews' author appears very reluctant-for reasons unknown to his readers-to invoke explicitly the significant connection of Noah with the blood commandments and his role as the pioneer of animal sacrificial practices. Despite this reluctance it is still possible that the author of Hebrews may have found more subtle ways to express his interest in these issues. Hebrews' attention to the issue of pre-Mosaic animal sacrificial practices appears to be implicitly reflected in chapter 11 . What is important here is that the author's attitude to the ancient sacerdotal rites appears shrouded in a rather enigmatic vocabulary connected with the imagery of righteousness. As we remember, chapter 11 , dealing with the issues of faith, provides a chain of important characters of primeval and Jewish history, briefly outlining their spiritual carriers. In the description of the heroes of the faith there, one can find several important qualities of these figures, including references to righteousness. Noting to whom righteousness is assigned is important. In the distinguished cohort of the heroes of primeval and Israelite history, only two persons were privileged to be described with the terminology of righteousness. First is Abel, who is designated as 'righteous' ( $\delta$ íka10 $\varsigma$ ), and second is Noah, who is named

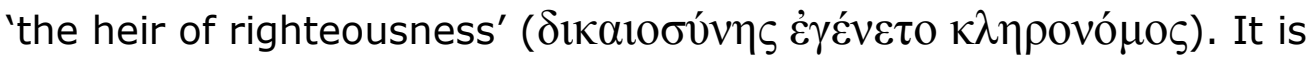
important for our investigation of the usage of righteousness to note that the description of the Abel story in Hebrews revolves around his sacrificial practices. ${ }^{37}$ Underlining the cultic emphasis of the passage, Pamela Eisenbaum observes that 'the author does not begin with the murder of Abel by Cain. He begins with the enigmatic biblical fact that Abel's sacrifice was accepted, while Cain's was not.' ${ }^{38}$ Oddly enough, the author also does not call attention to Abel's violent death; 39 he mentions only that Abel 'died', and eschews portraying him as a victim here. ${ }^{40}$ Eisenbaum notes that the author 'does add to the biblical text when he says that Abel "was attested to be righteous" ( $\dot{\varepsilon} \mu \alpha \rho \tau v \rho \eta \dot{\theta} \eta$ Eiv $\alpha$ dík $\alpha 10 \zeta)^{\prime} \cdot{ }^{41}$ In tracing the roots of this tradition, she proposes 
that one of the earliest references to the righteousness of Abel can be found in 1 Enoch 22:7, where he is said to be righteous. ${ }^{42}$ The possible Enochic/Noachic origin of this tradition is important for this study. Eisenbaum also points to another, possibly also 'Enochic', passage from the Testament of Abraham, chapter 13 (Recension A) and chapter 11 (Recension B), where Abel, again connected with the motif of righteousness, is portrayed as a judge who distinguishes the righteous from the wicked. ${ }^{43}$ These references drawn from the Jewish pseudepigraphic writings might indicate that the author of Hebrews in his depiction of Abel was cognizant of Enochic/Noachic traditions and applied them in his portrayal of the primeval hero. The author uses the terminology of righteousness again in Heb. 11:7 when speaking about Noah. The first part of the verse informs the reader that by faith Noah received an oracle concerning things not yet seen ( $\pi i ́ \sigma \tau \varepsilon 1$

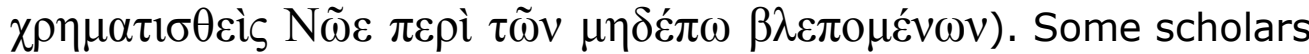
suggest that here again the author exhibits familiarity with the traditions attested in the Enochic lore where Noah, depicted as a mantic practitioner, receives God's warnings about the impending flood. ${ }^{44}$ The second part of verse 7 is even more interesting since here the author invokes the tradition about Noah becoming the heir of

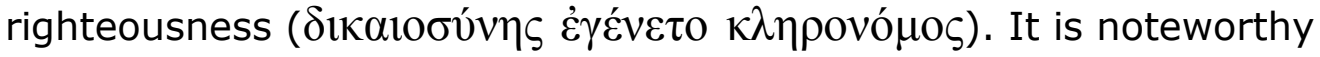
that while Noah is designated as the righteous person in the Genesis account, the epithet 'heir of righteousness' is not applied to him there. ${ }^{45}$ The LXX translation of Gen. 6:9 says that 'Noah was a righteous man ( $\delta$ ík $\alpha 10 \varsigma)^{\prime}$ but does not include the reference to Noah as the $\kappa \lambda \eta \rho o v o ́ \mu o s . ~{ }^{46}$

What does the word 'righteousness' mean in the context of the theological deliberations found in chapter 11 in particular and in the Epistle to the Hebrews in general? It is surprising that none of the other characters in chapter 11 is defined as righteous, despite that many of them are designated with this epithet in the Second Temple Jewish lore. Thus, for example, in 1 Enoch, the seventh antediluvian patriarch Enoch is defined as the righteous person and the scribe of righteousness. The Jewish pseudepigrapha, including the Testament of Abraham, also refer to Abraham as the righteous person. The Epistle to the Hebrews, however, is surprisingly reluctant to apply this designation to Enoch and Abraham. Why were the authors of Hebrews, who were willing to adopt the traditions about Abel as a righteous permission has been granted for this version to appear in e-Publications@Marquette. Oxford University Press does not grant permission for this article to be further copied/distributed or hosted elsewhere without the express permission from Oxford University Press. 
person from pseudepigraphical literature, reluctant to proceed with this title in the case of Enoch and Abraham?

The authors' choice in applying the important vocabulary of righteousness might indicate that in the context of the chapter and even the whole book this terminology might have a sacerdotal significance and perhaps even a more peculiar meaning, associated with sacrificial practices. It appears that the key to unlocking the mystery of the peculiar usage of the terminology of righteousness can be found in the already mentioned tradition from Heb. 11:4. There the author tells his readers that 'by faith Abel offered God a greater sacrifice than Cain, and through this he was commended as righteous, because God commended him for his offerings' ( $\pi i ́ \sigma \tau \varepsilon 1 \pi \lambda$ cíov $\alpha \theta v \sigma i ́ \alpha v$

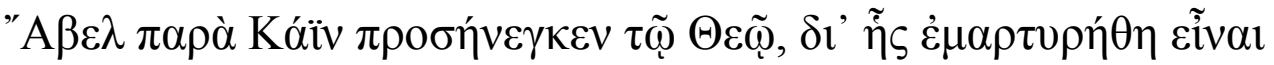

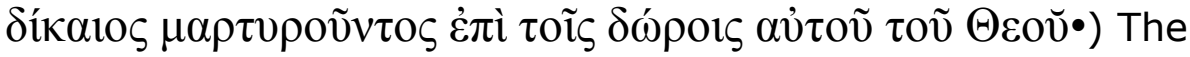
antecedent of the relative pronoun is not entirely clear here. Although the majority of translators prefer to translate $\delta \mathrm{i}^{\prime}$ iิ $\varsigma$ as 'through his [Abel's] faith', ${ }^{47}$ it can also be translated 'through his [Abel's] sacrifice'. While the theme of faith is the dominant leitmotif of chapter 11, in this particular verse the issue of Abel's offerings plays a paramount role. It is important therefore that the second part of the sentence puts additional emphasis on God's commendation of Abel for his offerings ( $\tau$ oĩ $\delta \omega ́ \rho 01 \zeta \alpha u ̛ \tau o \tilde{)}$ ).

As we remember, the terminology of righteousness is invoked for the second time in chapter 11 , verse 7 in connection with Noah. Although for some reason the author prefers not to speak openly about the animal sacrifices of Noah after his disembarkation, instead focusing on his role in the construction of the ark and deliverance from the Flood, the reference to Noah as the heir of righteousness

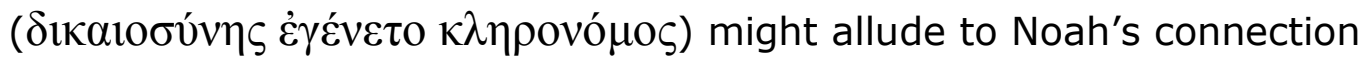
with the sacrificial practice in the view that the depiction of Abel's sacrifices was conveyed earlier through a similar terminology. ${ }^{48}$

It should be stressed again that only two primeval characters are described with the terminology of righteousness. What is even more interesting here is that both of them also represent two pivotal figures associated in the Bible with the animal sacrificial practices. Moreover, both of them can be seen as pioneers of these practices, Abel in the antediluvian time and Noah after the flood in the covenantal setting by sacrificing on the altar for the first time in the permission has been granted for this version to appear in e-Publications@Marquette. Oxford University Press does not grant permission for this article to be further copied/distributed or hosted elsewhere without the express permission from Oxford University Press. 
Bible. Noah's role as the official pioneer of the animal sacrificial cult is further reinforced by God's commandments about blood dispatched to the hero of the Flood immediately after his offerings on the altar. Michael Stone observes that Noah can be seen as the bridge between the antediluvian and post-diluvian worlds, serving as an important transmitter of the sacrificial tradition through the cataclysm of the Flood. 49

If the terminology of righteousness is indeed somehow connected with the tradition of animal sacrifices in the mind of Hebrews' author, it is not coincidental that this imagery has not been applied to other characters found in chapter 11 , who in fact did not belong to the distinctive cohort of the sacerdotal servants preoccupied with animal sacrificial rites. If we look further into how the terminology of righteousness was used elsewhere in the book we can see that besides Jesus, who of course is regarded by the author as the sacerdotal servant par excellence, the terminology of righteousness is applied to only one other character, the priest Melchizedek. It is he whose name is translated by the author of Hebrews as the king of

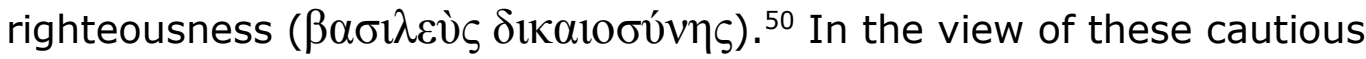
but precise attributions it is possible that through the terminology of righteousness, naming Noah as the heir of righteousness and Melchizedek as the king of righteousness, the author may be attempting to make an implicit connection between these two characters.

The question, however, remains: in what kind of connection does Noah as the heir of righteousness stand to Melchizedek as the king of righteousness and what does the author of the book try to accomplish through this terminological link? Does this link have a polemical significance? Does the author of Hebrews, like the author of 2 Enoch, try to depict Melchizedek as the sacerdotal counterpart of Noah? Are any qualities of Noah transferred to Melchizedek? All these questions will require another lengthy investigation.

Andrei Orlov

Marquette University andrei.orlov@marquette.edu permission has been granted for this version to appear in e-Publications@Marquette. Oxford University Press does not grant permission for this article to be further copied/distributed or hosted elsewhere without the express permission from Oxford University Press. 
NOT THE PUBLISHED VERSION; this is the author's final, peer-reviewed manuscript. The published version may be accessed by following the link in the citation at the bottom of the page.

\section{Notes:}

${ }^{1}$ On Moses traditions in the Epistle to the Hebrews, see E. L. Allen, 'Jesus and Moses in the New Testament', Expository Times 67 (1955-6), pp. 104-6; C. Chavasse, 'Jesus: Christ and Moses', Theologica 54 (1951), pp. 244-50; M. R. D'Angelo, Moses in the Letter to the Hebrews (SBLDS 42; Missoula, MT, 1979); E. Grässer, 'Mose und Jesus: Zur Auslegung von Hebr 3:1-6', ZNW 75 (1984), pp. 2-23; D. M. Hay, 'Moses through New Testament Spectacles', Interpretation 44 (1990), pp. 240-52; P. R. Jones, 'The Figure of Moses as a Heuristic Device for Understanding the Pastoral Intent of Hebrews', Review and Expositor 76 (1979), pp. 95-107. On Mosaic traditions, see also R. Bloch, 'Moïse dans la tradition rabbinique', in H. Cazelles (ed.), Moïse, I'homme de I'alliance (Tournai and New York, 1955), pp. 93-167; G. W. Coats, Moses: Heroic Man, Man of God (JSOTSup 57; Sheffeld, 1988); C. H. T. Fletcher-Louis, Luke-Acts: Angels, Christology and Soteriology (Tübingen, 1997); idem, '4Q374: A Discourse on the Sinai Tradition: The Deification of Moses and Early Christianity', DSD 3 (1996), pp. 236-52; idem, All the Glory of Adam: Liturgical Anthropology in the Dead Sea Scrolls (STDJ 42; Leiden, 2002), pp. 136 V.; J. Fossum, The Name of God and the Angel of the Lord: Samaritan and Jewish Concepts of Intermediation and the Origin of Gnosticism (WUNT 36; Tübingen, 1985), pp. 90-4; S. J. Hafemann, 'Moses in the Apocrypha and Pseudepigrapha: A Survey', JSP 7 (1990), pp. 79-104; C. R. Holladay, 'The Portrait of Moses in Ezekiel the Tragedian', SBLSP 10 (1976), pp. 447-52; P. W. van der Horst, 'Moses' Throne Vision in Ezekiel the Dramatist', JJS 34 (1983), pp. 21-9; idem, 'Some Notes on the Exagoge of Ezekiel', Mnemosyne 37 (1984), pp. 364-5; L. Hurtado, One God, One Lord: Early Christian Devotion and Ancient Jewish Monotheism (Philadelphia, 1988), 58 V.; H. Jacobsen, The Exagoge of Ezekiel (Cambridge, 1983); K. Kuiper, 'Le Poète juif Ezéchiel', Revue des études juives 46 (1903), pp. 174 V.; W. A. Meeks, 'Moses as God and King', in J. Neusner (ed.), Religions in Antiquity: Essays in Memory of Erwin Ramsdell Goodenough (Leiden, 1968), pp. 354-71; idem, The Prophet-King: Moses Traditions and the Johannine Christology (SNT 14; Leiden, 1967); A. Orlov, 'Ex 33 on God's Face: A Lesson from the Enochic Tradition', SBLSP 39 (2000), pp. 130-47; A. Schalit, Untersuchungen zur Assumptio Mosis (Leiden, 1989); J. P. Schultz, 'Angelic Opposition to the Ascension of Moses and the Revelation of the Law', JQR 61 (1970-1), pp. 282-307; J. Tromp, The Assumption of Moses: A Critical Edition with Commentary (Leiden, 1993); R. Van De Water, 'Moses' Exaltation: Pre-Christian?' JSP 21 (2000), pp. 59-69.

Journal of Theological Studies, Vol 58, No. 1 (April 2007): pg. 45-65. DOl. This article is (c) Oxford University Press and permission has been granted for this version to appear in e-Publications@Marquette. Oxford University Press does not grant permission for this article to be further copied/distributed or hosted elsewhere without the express permission from Oxford University Press. 
NOT THE PUBLISHED VERSION; this is the author's final, peer-reviewed manuscript. The published version may be accessed by following the link in the citation at the bottom of the page.

2 On Melchizedek traditions, see I. Amusin, 'Novyj eshatologicheskij tekst iz Kumrana (11QMelchizedek)', Vestnik Drevnej Istorii 3 (1967), pp. 4562; idem, Teksty Kumrana (Pamjatniki pis'mennosti vostoka, 33/1; Moscow, 1971); V. Aptowitzer, 'Malkizedek: Zu den Sagen der Agada', Monatschrift für Geschichte und Wissenschaft des Judentums 70 (1926), pp. 93-113; A. Aschim, 'Melchizedek the Liberator: An Early Interpretation of Genesis 14?', in SBLSP 35 (1996), pp. 243-58; C. Böttrich, 'The Melchizedek Story of 2 (Slavonic) Enoch: A Reaction to A. Orlov', JJS 32/4 (2001), pp. 445-70; A. Caquot, 'La Pérennité du sacerdoce', Paganisme, Judaïsme, Christianisme (Paris, 1978), pp. 109-16; A. R. Carmona, 'La figura de Melquisedec en la leteratura targumica', Estudios bíblicos 37 (1978), pp. 79-102; G. L. Cockerill, The Melchizedek Christology in Heb. 7:1-28 (Ann Arbor, 1979); J. Davila, 'Melchizedek, Michael, and War in Heaven', SBLSP 35 (1996), pp. 259-72; idem, 'Melchizedek: King, Priest, and God', in S. Daniel Breslauer (ed.), The Seductiveness of Jewish Myth: Challenge or Response? (Albany, NY, 1997), pp. 217-34; idem, 'Melchizedek, the "Youth", and Jesus', in The Dead Sea Scrolls as Background to Postbiblical Judaism and early Christianity: Papers from an International Conference at St. Andrews in 2001, ed. J. R. Davila (STDJ 46; Leiden, 2003), pp. 248-74; M. De Jonge and A. S. Van der Woude, '11QMelchizedek and the New Testament', NTS 12 (1965-6), pp. 301-26; M. Delcor, 'Melchizedek from Genesis to the Qumran texts and the Epistle to the Hebrews', JSJ 2 (1971), pp. 115-35; F. du Toit Laubscher, 'God's Angel of Truth and Melchizedek: A Note on $11 \mathrm{Q}$ Melch 13b', JSJ 3 (1972), pp. 46-51; J. Fitzmyer, 'Further Light on Melchizedek from Qumran Cave 11', Essays on the Semitic Background of the New Testament (SBLSBS, 5; Missoula, MT, 1974), pp. 245-67; idem, ' "Now This Melchizedek . .." (Heb. 7:1)', in Essays on the Semitic Background of the New Testament (SBLSBS 5; Missoula, MT, 1974), pp. 221-43; idem, 'Melchizedek in the MT, LXX, and the NT', Biblica 81 (2000), pp. 63-9; J. Gammie, 'Loci of the Melchizedek Tradition of Gen. 14:18-20', JBL 90 (1971), pp. 385-96; F. García Martínez, '4Q Amram B 1:14; ¿Melkiresa o Melki-sedeq?' Revue de Qumran 12 (1985), pp. 111-14; idem, 'Las tradiciones sobre Melquisedec en los manuscritos de Qumrán', Biblica 81 (2000), pp. 70-80; C. Gianotto, Melchizedek e la sua tipologia: Tradizioni giudiche, cristiane e gnostiche (sec II a.C.-sec.III d.C) (SrivB, 12; Brescia, 1984); I. Gruenwald, 'The Messianic Image of Melchizedek', Mahanayim 124 (1970), pp. 88-98 (in Hebrew); F. Horton, The Melchizedek Tradition: A Critical Examination of the Sources to the Fifth Century A.D. and in the Epistle to the Hebrews (SNTSMS, 30; Cambridge/London/New York/Melbourne, 1976); P. Kobelski, permission has been granted for this version to appear in e-Publications@Marquette. Oxford University Press does not grant permission for this article to be further copied/distributed or hosted elsewhere without the express permission from Oxford University Press. 
NOT THE PUBLISHED VERSION; this is the author's final, peer-reviewed manuscript. The published version may be accessed by following the link in the citation at the bottom of the page.

Melchizedek and Melchirešac (CBQMS 10; Washington, DC, 1981); R. N. Longenecker, 'The Melchizedek Argument of Hebrews: A Study in the Development and Circumstantial Expression of New Testament Thought', in R. Guelich (ed.), Unity and Diversity in New Testament Theology (Grand Rapids, MI, 1978), pp. 161-85; J. L. Marshall, 'Melchizedek in Hebrews, Philo, and Justin Martyr', SE 7 (1982), pp. 339-42; M. McNamara, 'Melchizedek: Gen 14, 17-20 in the Targums, in Rabbinic and Early Christian Literature', Biblica 81 (2000), pp. 1-31; O. Michel, 'Melchizedek', TDNT 4.568-71; A. Orlov, 'Melchizedek Legend of 2 (Slavonic) Enoch', JSJ 31 (2000), pp. 23-38; B. Pearson, 'The Figure of Melchizedek in the First Tractate of the Unpublished Coptic-Gnostic Codex IX from Nag Hammadi', in Proceedings of the XIIth International Congress of the International Association for the History of Religion (Supplements to Numen, 31; Leiden, 1975), pp. 200-8; idem, 'The Figure Melchizedek in Gnostic Literature', in Gnosticism, Judaism and Egyptian Christianity (Minneapolis, 1990), pp. 108-23; J. Petuchowski, 'The Controversial Figure of Melchizedek', HUCA 28 (1957), pp. 127-36; S. E. Robinson, 'The Apocryphal Story of Melchizedek', JSJ 18 (1987), pp. 26-39; D. W. Rooke, 'Jesus as Royal Priest: Reflections on the Interpretation of the Melchizedek Tradition in Heb 7', Biblica 81 (2000), pp. 81-94; H. Rowley, 'Melchizedek and Zadok (Gen 14 and Ps 110)', in Festschrift für Alfred Bertholet zum 80. Geburtstag (Tübingen, 1950), 461-72; C. Schmidt and V. MacDermot, The Books of Jeu and the Untitled Text in the Bruce Codex (NHS 13; Leiden, 1978); M. Simon, 'Melchisédech dans la polémique entre juifs et chrétiens et dans la légende', Revue $d$ 'histoire et de philosophie religieuses 17 (1937), pp. 58-93; R. Smith, 'Abram and Melchizedek (Gen. 14, 18-20)', Zeitschrift für die Alttestamentliche Wissenschaft 87 (1965), pp. 129-53; C. Spicq, 'Melchisédech et l'Épître aux Hébreux', Esprit et Vie 87 (1977), pp. 206-8; H. Stork, Die sogenannten Melchizedekianer mit Untersuchungen ihrer Quellen auf Gedankengehalt und dogmengeschichtliche Entwicklung (Forschungen zur Geschichte des neutestamentlichen Kanons und der altkirchlichen Literatur, 8/2; Leipzig, 1928); G. Vajda, 'Melchisédec dans la mythologie ismaélienne', Journal Asiatique 234 (1943-5), pp. 173-83; G. Wuttke, Melchisedech der Priesterkönig von Salem: Eine Studie zur Geschichte der Exegese (BZNW, 5; Giessen, 1927).

${ }^{3}$ On Noachic traditions, see M. Bernstein, 'Noah and the Flood at Qumran', in The Provo International Conference on the Dead Sea Scrolls: Technological Innovations, New Texts, and Reformulated Issues, ed. D. W. Parry and E. Ulrich (STDJ 30; Leiden, 1999), pp. 199-231; D. Dimant, 'Noah in Early Jewish Literature', in M. E. Stone and T. A. permission has been granted for this version to appear in e-Publications@Marquette. Oxford University Press does not grant permission for this article to be further copied/distributed or hosted elsewhere without the express permission from Oxford University Press. 
NOT THE PUBLISHED VERSION; this is the author's final, peer-reviewed manuscript. The published version may be accessed by following the link in the citation at the bottom of the page.

Bergren (eds.), Biblical Figures outside the Bible (Harrisburg, PA, 1998), pp. 23-50; F. García Martínez, Qumran and Apocalyptic (STDJ 9; Leiden, 1992), pp. 24-44; idem, 'Interpretation of the Flood in the Dead Sea Scrolls', in F. García Martínez and G. P. Luttikhuizen (eds.), Interpretations of the Flood (TBN 1; Leiden, 1998), pp. 86-108; N. Koltun-Fromm, 'Aphrahat and the Rabbis on Noah's Righteousness in Light of the Jewish-Christian Polemics', in J. Frishman and L. Van Rompay (eds.), The Book of Genesis in Jewish and Oriental Christian Interpretation (TEG 5; Leuven, 1997), pp. 57-71; H. Kvanvig, Roots of Apocalyptic: The Mesopotamian Background of the Enoch Figure and the Son of Man (WMANT 61; Neukirchen-Vluyn, 1988), pp. 242-54; J. Lewis, A Study of the Interpretation of Noah and the Flood in Jewish and Christian Literature (Leiden, 1968); A. Orlov, ' "Noah's Younger Brother": Anti-Noachic Polemics in 2 Enoch', Henoch 22/2 (2000), pp. 259-73; idem, 'Noah's Younger Brother Revisited: Anti-Noachic Polemics and the Date of 2 (Slavonic) Enoch', Henoch 26/2 (2004), pp. 172-87; idem, The Enoch-Metatron Tradition (TSAJ 107; Tübingen, 2005), pp. 304-33; J. Reeves, 'Utnapishtim in the Book of Giants?' JBL 12 (1993), pp. 110-15; J. M. Scott, 'Geographic Aspects of Noachic Materials in the Scrolls of Qumran', in S. E. Porter and C. E. Evans (eds.), The Scrolls and the Scriptures: Qumran Fifty Years After (JSPS 26; Sheffeld, 1997), pp. 368-81; R. C. Steiner, 'The Heading of the Book of the Words of Noah on a Fragment of the Genesis Apocryphon: New Light on a "Lost" Work', DSD 2 (1995), pp. 66-71; M. Stone, 'The Axis of History at Qumran', in E. Chazon and M. E. Stone (eds.), Pseudepigraphic Perspectives: The Apocrypha and the Pseudepigrapha in Light of the Dead Sea Scrolls (STDJ 31; Leiden, 1999), pp. 133-49; idem, 'Noah, Books of', Encyclopaedia Judaica (Jerusalem, 1971), vol. 12, p. 1198; J. VanderKam, 'The Righteousness of Noah', in J. J. Collins and G. W. E. Nickelsburg (eds.), Ideal Figures in Ancient Judaism: Profiles and Paradigms (SBLSCS 12; Chico, Calif., 1980), pp. 13-32; idem, 'The Birth of Noah', in Z. J. Kapera (ed.), Intertestamental Essays in Honor of Jósef Tadeusz Milik (Qumranica Mogilanensia, 6; Kraków, 1992), pp. 213-31; Cana Werman, 'Qumran and the Book of Noah', in Chazon and Stone (eds.), Pseudepigraphic Perspectives, pp. 171-81.

${ }^{4}$ On the priestly profile of Enoch, see M. Himmelfarb, 'The Temple and the Garden of Eden in Ezekiel, the Book of the Watchers, and the Wisdom of ben Sira', in J. Scott and P. Simpson-Housley (eds.), Sacred Places and Profane Spaces: Essays in the Geographics of Judaism, Christianity, and Islam (New York, 1991), pp. 63-78; idem, 'Apocalyptic Ascent and the Heavenly Temple', SBLSP 26 (1987), pp. 210-17; J. VanderKam, Enoch and the Growth of an Apocalyptic

Journal of Theological Studies, Vol 58, No. 1 (April 2007): pg. 45-65. DOl. This article is (c) Oxford University Press and permission has been granted for this version to appear in e-Publications@Marquette. Oxford University Press does not grant permission for this article to be further copied/distributed or hosted elsewhere without the express permission from Oxford University Press. 
NOT THE PUBLISHED VERSION; this is the author's final, peer-reviewed manuscript. The published version may be accessed by following the link in the citation at the bottom of the page.

Tradition (The Catholic Biblical Quarterly Monograph Series 16; Washington, DC, 1984); idem, Enoch: A Man for All Generations (Columbia, SC, 1995); H. Kvanvig, Roots of Apocalyptic, pp. 101-2. See also J. Maier, 'Das Gefa"hrdungsmotiv bei der Himmelsreise in der ju“ dischen Apocalyptik und 'Gnosis',' Kairos 5/1 (1963), pp. 18-40, esp. p. 23; idem, Vom Kultus zur Gnosis (Kairos 1; Salzburg, 1964), pp. 127-8; G. W. E. Nickelsburg, 'Enoch, Levi, and Peter: Recipients of Revelation in Upper Galilee', JBL 100 (1981), pp. 575-600, esp. pp. 576-82; D. Halperin, The Faces of the Chariot: Early Jewish Responses to Ezekiel's Vision (TSAJ 16; Tübingen, 1988), p. 81; G. Boccaccini, Beyond the Essene Hypothesis: The Parting of the Ways Between Qumran and Enochic Judaism (Grand Rapids, MI, 1998).

5 See e.g. 2 Enoch 58-9.

61 Enoch 106:5: 'his eyes (are) like the rays of the sun, and his face glorious'; M. Knibb, The Ethiopic Book of Enoch: A New Edition in the Light of the Aramaic Dead Sea Fragments, 2 vols. (Oxford, 1978), vol. 2, pp. 244-5.

71 QapGen 5:12-13 'his face has been lifted to me and his eyes shine like [the] s[un ... .] (of) this boy is flame and he'; F. García Martínez and E. J. C. Tigchelaar (eds.), The Dead Sea Scrolls Study Edition, 2 vols. (Leiden/New York/Cologne, 1997), vol. 1, p. 31.

81 Q19 3: 'were aston[ished ... .] [. . . (not like the children of men) the fir]stborn is born, but the glorious ones [. . .] [. . .] his father, and when Lamech saw [. . . [ [. . ] the chambers of the house like the beams of the sun [...] to frighten the [. . . .' 1Q19 13: '[. . .] because the glory of your face [. . .] for the glory of God in [. . .] [. . . he will] be exalted in the splendor of the glory and the beauty [. . .] he will be honored in the midst of [. . .].' García Martínez and Tigchelaar (eds.), The Dead Sea Scrolls Study Edition, vol. 1, p. 27.

${ }^{9}$ Fletcher-Louis, All the Glory of Adam, pp. 33 V.

${ }^{10}$ Crispin Fletcher-Louis notes parallels between this scene and the description of the ideal high priest from Sirach 50 . He argues that 'in Sirach 50 the liturgical procession through Simon's various ministrations climaxes with Aaron's blessings of the people (50:20, cf. Numbers 6) and a call for all the readers of Sirach's work "to bless the God of all who everywhere works greater wonders, who fosters our growth from birth and deals with us according to his mercy" (50:22). So, too, in 1 Enoch 106:3 the infant Noah rises from the hands of the midwife and, already able to speak as an adult, "he opened his mouth and blessed the Lord".' All the Glory of Adam, p. 47.

${ }^{11}$ Fletcher-Louis argues that 'the staging for [Noah's] birth and the behavior of the child have strongly priestly resonances'; ibid., p. 46.

Journal of Theological Studies, Vol 58, No. 1 (April 2007): pg. 45-65. DOI. This article is @ Oxford University Press and permission has been granted for this version to appear in e-Publications@ Marquette. Oxford University Press does not grant permission for this article to be further copied/distributed or hosted elsewhere without the express permission from Oxford University Press. 
NOT THE PUBLISHED VERSION; this is the author's final, peer-reviewed manuscript. The published version may be accessed by following the link in the citation at the bottom of the page.

12 Noachic polemics take place in the last chapters of the Slavonic apocalypse (chs. 68-72). In this section of the pseudepigraphon we learn that, immediately after Enoch's instructions to his sons during his short visit to the earth and his ascension to the highest heaven, the firstborn son of Enoch, Methuselah, and his brothers, the sons of Enoch, constructed an altar at Achuzan, the place where Enoch had been taken up. In 2 Enoch 69 the Lord appeared to Methuselah in a night vision and appointed him as priest before the people. Verses 11-16 of this chapter describe the first animal sacrifice of Methuselah on the altar. The text gives an elaborate description of the sacrificial ritual during which Methuselah slaughters with a knife, 'in the required manner', sheep and oxen placed at the head of the altar. All these sheep and oxen are tied according to the sectarian instructions given by Enoch earlier in the book. Chapter 70 of 2 Enoch recounts the last days of Methuselah on earth before his death. The Lord appeared to Methuselah in a night vision and commanded him to pass his priesthood duties on to the second son of Lamech, the previously unknown Nir. The text does not explain why the Lord wanted to pass the priesthood to Nir instead of Noah (Lamech's firstborn son), even though Noah is also mentioned in the dream. Further, the book tells that Methuselah invested Nir with the vestments of priesthood before the face of all the people and 'made him stand at the head of the altar'. The account of the sacerdotal practices of Enoch's relatives then continues with the Melchizedek story. The content of the story is connected with Nir's family. Sothonim, Nir's wife, gave birth to a child 'in her old age', right 'on the day of her death'. She conceived the child, 'being sterile' and 'without having slept with her husband'. The book narrated that Nir the priest had not slept with her from the day that the Lord had appointed him in front of the face of the people. Therefore, Sothonim hid herself during all the days of her pregnancy. Finally, when she was at the day of birth, Nir remembered his wife and called her to himself in the temple. She came to him and he saw that she was pregnant. Nir, filled with shame, wanted to cast her from him, but she died at his feet. Melchizedek was born from Sothonim's corpse. When Nir and Noah came in to bury Sothonim, they saw the child sitting beside the corpse with 'his clothing on him'. According to the story, they were terrified because the child was fully developed physically. The child spoke with his lips and he blessed the Lord. According to the story, the newborn child was marked with the sacerdotal sign, the glorious 'badge of priesthood' on his chest. Nir and Noah dressed the child in the garments of priesthood and they fed him the holy bread. They decided to hide him, fearing that the people would have him put to death. Finally, the Lord commanded His permission has been granted for this version to appear in e-Publications@Marquette. Oxford University Press does not grant permission for this article to be further copied/distributed or hosted elsewhere without the express permission from Oxford University Press. 
archangel Gabriel to take the child and place him in 'the paradise Eden' so that he might become the high priest after the Flood. The final passages of the story describe the ascent of Melchizedek on the wings of Gabriel to the paradise Eden.

13 See M. Delcor, 'Melchizedek from Genesis to the Qumran Texts and the Epistle to the Hebrews', JSJ 2 (1971), p. 129; idem, 'La Naissance merveilleuse de Melchise' deq d'apre 's I'He'noch slave', in C. Augustin et al. (eds.), Kecharitomene: Mélanges René Laurentin (Paris, 1990), pp. 217-29; G. W. E. Nickelsburg, Jewish Literature between the Bible and the Mishnah (Philadelphia, 1981), p. 185; A. de Santos Otero, 'Libro de los secretos de Henoc (Henoc eslavo)', in A. Di' es Macho (ed.), Apocrifos del Antiguo Testamento, 4 vols. (Madrid, 1984), vol. 4, p. 199; R. Stichel, Die Namen Noes, seines Bruders und seiner Frau: Ein Beitrag zum Nachleben jüdischer Überlieferungen in der außerkanonischen und gnostischen Literatur und in Denkmälern der Kunst (AAWG.PH 3. Folge 112; Göttingen, 1979), pp. 42-54.

${ }^{14}$ F. Andersen, '2 (Slavonic Apocalypse of) Enoch', in The Old Testament Pseudepigrapha, ed. J.H.Charlesworth, 2 vols.(NewYork, 1985 [1983]), vol. 1,p. 207.

15 Delcor, 'Melchizedek from Genesis to the Qumran Texts', p. 129.

16 George Nickelsburg observes that the miraculous circumstances attending Melchizedek's conception and birth are reminiscent of the Noah story in 1 Enoch, although the suspicion of Nir is more closely paralleled in the version of the Noah story in the Genesis Apocryphon. G. W. E. Nickelsburg, Jewish Literature between the Bible and the Mishnah (Philadelphia, 1981), p. 188.

17 García Martínez and Tigchelaar (eds.), The Dead Sea Scrolls Study Edition, vol. 1, p. 29.

18 Andersen, '2 Enoch', p. 205.

19 García Martínez and Tigchelaar (eds.), The Dead Sea Scrolls Study Edition, vol. 1, p. 29.

20 Ibid., pp. 29-31.

${ }^{21}$ Andersen, '2 Enoch', p. 205.

221 Enoch 106:16-18: 'And this son who has been born unto you shall be left upon the earth, and his three sons shall be saved when they who are upon the earth are dead.' 2 Enoch 71:29-30: 'And this child will not perish along with those who are perishing in this generation, as I have revealed it, so that Melchizedek will be ... the head of the priests of the future.' It is noteworthy that this information is given in both cases in the context of the revelation about the destruction of the earth by the Flood. Andersen, '2 Enoch', p. 208.

23 J. VanderKam, The Book of Jubilees, 2 vols. (CSCO 510-11; Scriptores Aethiopici 87-8; Leuven, 1989), vol. 2, p. 60. permission has been granted for this version to appear in e-Publications@Marquette. Oxford University Press does not grant permission for this article to be further copied/distributed or hosted elsewhere without the express permission from Oxford University Press. 
${ }^{24}$ Only the $T g$. Onq. does not mention Shem in connection with Melchizedek. Interestingly, $\mathrm{Tg}$. Onq. is the only targum that also shows a negative attitude towards Enoch: 'and Enoch walked in reverence of the Lord, then he was no more, for the Lord has caused him to die (Gen. 5:24)'. The Targum Onkelos to Genesis, trans. B. Grossfeld (Aramaic Bible, 6; Wilmington, Del., 1988), p. 52.

25 Targum Neofiti 1: Genesis, trans. M. McNamara (AB, 1A; Collegeville, Minn., 1992), p. 92.

26 Targum Pseudo-Jonathan: Genesis, trans. M. Maher (AB, 1B; Collegeville, Minn., 1992), p. 58.

27 The Babylonian Talmud. Seder Nedarim (London, 1936), pp. 98-9.

28 Two other important rabbinic attestations of Melchizedek as Shem include

Pirke R. El. and Gen. Rab. Pirke R. El. has two references to Melchizedek-Shem. The first reference occurs in the passage on the handling of the tradition of intercalation among the Patriarchs. The text says that 'Noah handed on the tradition to Shem, and he was initiated in the principle of intercalation; he intercalated the years and he was called a priest, as it is said, "And Melchizedek king of Salem . . . was a priest of God Most High" (Gen 14:18). Was Shem the Son of Noah a priest? But because he was the first-born, and because he ministered to his God by day and by night, therefore was he called a priest.' Pirke de Rabbi Eliezer, trans. G. Friedländer (New York, 1965), p. 53. The other reference to Melchizedek-Shem in Pirke R. El. occurs in ch. 28: 'Rabbi Joshua said: Abraham was the first to begin to give a tithe. He took all the tithe of the kings and all the tithe of the wealth of Lot, the son of his brother, and gave (it) to Shem, the Son of Noah, as it is said, "And he gave him a tenth of all".' Ibid., p. 195.

29 P. Eisenbaum, The Jewish Heroes of Christian History: Hebrews 11 in Literary Context (Atlanta, Ga., 1995), pp. 148-9; B. Heinninger, 'Hebr 11.7 und das Henochorakel an Ende der Welt', New Testament Studies 44 (1998), pp. 115-32.

302 Enoch 71:32-3 (longer recension): 'Therefore honor him [Melchizedek] with your servants and great priests, with Sit, and Enos, and Rusi, and Amilam, and Prasidam, and Maleleil, and Serokh, and Arusan, and Aleem, and Enoch, and Methusalam, and me, your servant Nir.' Andersen, '2 Enoch', p. 208.

31 See n. 30

32 Pearson stresses the fact that Jewish apocalyptic elements are prominent in Melch. He argues that 'it might be suggested that Melch. is a JewishChristian product containing an originally pre-Christian Melchizedek speculation overlaid with Christian Christological re-interpretation'. Nag Hammadi Codices IX and X, ed. Birger A. Pearson (NHS 15; Leiden, 1981), p. 34.

Journal of Theological Studies, Vol 58, No. 1 (April 2007): pg. 45-65. DOl. This article is (c) Oxford University Press and permission has been granted for this version to appear in e-Publications@Marquette. Oxford University Press does not grant permission for this article to be further copied/distributed or hosted elsewhere without the express permission from Oxford University Press. 
NOT THE PUBLISHED VERSION; this is the author's final, peer-reviewed manuscript. The published version may be accessed by following the link in the citation at the bottom of the page.

33 'of Adam [Abel], Enoch, [Noah] you, Melchizedek, [the Priest] of God [Most High] (12:7-11)'. Nag Hammadi Codices IX and X, ed. Pearson, p. 63.

${ }^{34}$ It is noteworthy that the motif of blood, both animal and human, represents one of the pivotal theological themes in the book. The word 'blood' appears more often than in any other New Testament writing besides the Book of Revelation. The Greek term $\alpha \tilde{i} \mu \alpha$ occurs a total of twenty-one times in the pamphlet, of which no fewer than fourteen are found in the ninth and tenth chapters. William Johansson's research demonstrates that in the Epistle to the Hebrews the imagery of blood has a very strong cultic meaning and 'is set worth as the medium of power . . . specifically: blood provides access to God (9:7, 12, 25; 10:19); blood sanctifies, or consecrates (9:13); blood cleanses (9:14, $22)$; blood inaugurates covenant $(9: 20 ; 10: 29)$; blood perfects $(9: 9$, $14 ; 10: 14)$; blood brings $\ddot{\alpha} \phi \varepsilon \sigma l \varsigma(9: 22)$ '. Johansson, 'Defilement and Purgation in the Book of Hebrews' (Ph.D. diss., Vanderbilt University, 1973), pp. 229-30.

35 Johansson notes that in the book the nature of blood as power comes to expression most clearly in terms of comparisons and contrasts as the blood of animals is juxtaposed to that of Jesus'. This contrast between animal blood and the blood of Jesus invokes the contrast earlier detected in Noah's passage from Genesis 9 where human and animal blood is contrasted with different theological outcomes. Another similarity is that in both accounts human blood has more power than animal blood. In Genesis 9 it has more power because shedding this blood brings more serious consequences-death. Johansson observes that in the Epistle to the Hebrews 'Jesus's blood is the more powerful medium: this is the conclusion which the author wants to make. The comparison and contrast come into the sharpest focus at 9:13,14-if the blood of goats and bulls avail to the extent of the purgation

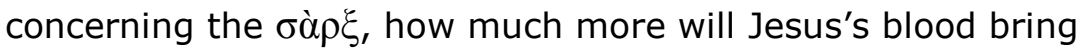
purgation of conscience for true worship.' Johansson, 'Defilement and Purgation', pp. 229-30.

36 Gen. 8:20-9:6: 'Then Noah built an altar to the LORD, and took of every clean animal and of every clean bird, and offered burnt offerings on the altar. And when the LORD smelled the pleasing odor, the LORD said in his heart, "I will never again curse the ground because of humankind, for the inclination of the human heart is evil from youth; nor will I ever again destroy every living creature as I have done. As long as the earth endures, seedtime and harvest, cold and heat, summer and winter, day and night, shall not cease." God blessed Noah and his sons, and said to them, "Be fruitful and multiply, and fill the earth. The fear and dread of you shall rest on every animal of the earth, and on every bird of the air, on everything that creeps on the permission has been granted for this version to appear in e-Publications@Marquette. Oxford University Press does not grant permission for this article to be further copied/distributed or hosted elsewhere without the express permission from Oxford University Press. 
ground, and on all the fish of the sea; into your hand they are delivered. Every moving thing that lives shall be food for you; and just as I gave you the green plants, I give you everything. Only, you shall not eat flesh with its life, that is, its blood. For your own lifeblood I will surely require a reckoning: from every animal I will require it and from human beings, each one for the blood of another, I will require a reckoning for human life. Whoever sheds the blood of a human, by a human shall that person's blood be shed; for in his own image God made humankind."

37 On Abel traditions, see V. Aptowitzer, Kain und Abel in der Agada, den Apokryphen, der hellenistischen, christlichen und muhammedanischen Literatur (Vienna and Leipzig, 1922), esp. pp. 37-55; J. M. Bassler, 'Cain and Abel in the Palestinian Targums: A Brief Note on an Old Controversy', JJS 17 (1986), pp. 56-64; J. B. Bauer, 'Kain und Abel', TPQ 103 (1955), pp. 126-33; S. Bénétreau, 'La Foi d'Abel: Hébreux 11/4', ETR 54 (1979), pp. 623-30; S. Brock, 'A Syriac Life of Abel', Muséon 87 (1974), pp. 467-92; P. Grelot, 'Les Targums du Pentateuque', Semitica 9 (1959), pp. 59-88; R. Le Déaut, 'Traditions targumiques dans le corpus paulinien? (Hébr 11,4 et 12,24; Gal 4,2930; II Cor 3,16)', Biblica 42 (1961), pp. 24-48; G. Vermes, 'The Targumic Versions of Genesis 4,3-16', ALUOS 3 (1961-2), pp. 81114.

38 P. Eisenbaum, The Jewish Heroes of Christian History: Hebrews 11 in Literary Context (Atlanta, Ga., 1995), p. 148.

${ }^{39}$ In Heb. 12:24 the author of the Epistle compares the spilled blood of Jesus with Abel; in ch. 11, however, there is no typological relation between the blood of Abel and the blood of Jesus. See Eisenbaum, The Jewish Heroes of Christian History, p. 149.

40 Ibid.

${ }^{41}$ Ibid., p. 148.

42 See also H. W. Attridge, The Epistle to the Hebrews (Hermeneia; Philadelphia, 1989), p. 316, n. 136.

${ }^{43}$ Eisenbaum observes that 'in 1 Enoch 22:7V and T. Abr 13, Abel resides in heaven and is portrayed as a judge who distinguishes the righteous from the wicked. Since Abel as the righteous one is connected to the image of Abel as judge, it is likely that our author knows the latter tradition as well as the former. In the Enoch passage the souls of the righteous are taken up while the wicked are left behind, buried in the earth-at Abel's discretion. The true home of the righteous is the divine realm, while that of the unrighteous is in the earth in its material sense. Abel therefore initiates the process of separating the righteous from the wicked, and at the same time becomes the first 
NOT THE PUBLISHED VERSION; this is the author's final, peer-reviewed manuscript. The published version may be accessed by following the link in the citation at the bottom of the page.

righteous one to reach the divine realm.' Eisenbaum, The Jewish Heroes of Christian History, pp. 149-50.

44 The author's knowledge of Enochic/Noachic tradtions, especially in connection with the motif of warning of Noah in 11:7 and Noah's role as the mantic visionary, have been investigated by Bernard Heinninger in his article 'Hebr 11.7 und das Henochorakel am Ende der Welt', New Testament Studies 44 (1998), pp. 115-32.

${ }^{45}$ See also Gen. 7:1; Ezek. 14:14, 20; Sir. 44:17; Wis. 10:4.

46 Harold Attridge observes that 'the remark that Noah was an "heir of righteousness" is not traditional'. Attridge, The Epistle to the Hebrews, p. 320.

47 Cf. C. Spicq, L'Épître aux Hébreux, 2 vols. (Paris, 1952-3), vol. 2, p. 342; Attridge, The Epistle to the Hebrews, p. 316; W. L. Lane, Hebrews 913 (WBC, 47B; Nashville, 1991), p. 327.

${ }^{48}$ In his classic study on the motif of Noah's righteousness, James VanderKam demonstrates that this motif was employed in the Second Temple materials for diVerent literary ends. Thus, for example, the author of Jubilees 'sketches a portrait of a priestly Noah whose righteousness consists in obedience to sacerdotal legislation'; VanderKam, 'The Righteousness of Noah', p. 20.

49 He stresses that 'the sudden clustering of works around Noah indicates that he was seen as a pivotal figure in the history of humanity, as both an end and a beginning'. Stone, 'The Axis of History at Qumran', p. 141.

50 Heb. 7:2.

Journal of Theological Studies, Vol 58, No. 1 (April 2007): pg. 45-65. DOI. This article is @ Oxford University Press and permission has been granted for this version to appear in e-Publications@Marquette. Oxford University Press does not grant permission for this article to be further copied/distributed or hosted elsewhere without the express permission from Oxford University Press. 